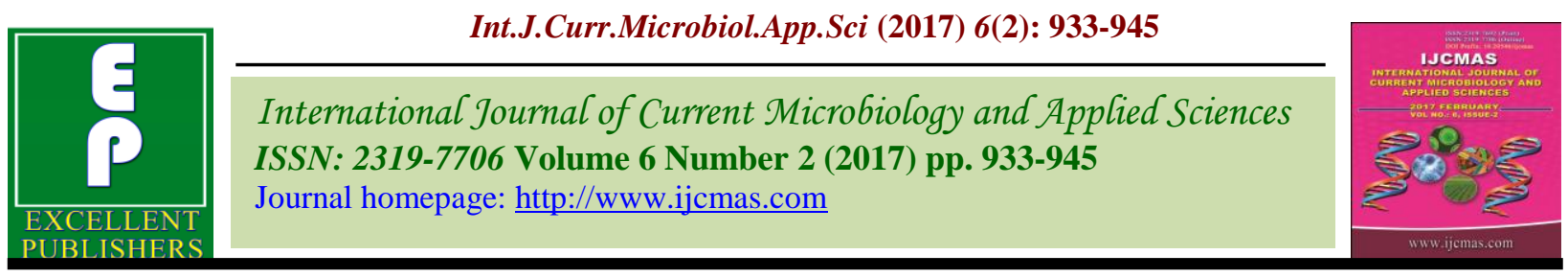

Original Research Article

http://dx.doi.org/10.20546/ijcmas.2017.602.104

\title{
Biofunctional Properties of Cultured Buttermilk Prepared by Incorporation of Fermented Paneer Whey
}

\author{
Sonali L. Parekh*, Smitha Balakrishnan, Subrota Hati and K.D. Aparnathi \\ Department of Dairy Chemistry, SMC College of Dairy Science, Anand Agricultural University, \\ Anand-388110, India \\ *Corresponding author
}

\begin{tabular}{|c|c|}
\hline & A B S T R A C T \\
\hline $\begin{array}{l}\text { K e y w o r d s } \\
\text { Paneer whey, } \\
\text { Cultured buttermilk, } \\
\text { Bioactive peptides, } \\
\text { Fermentation, } \\
\text { Biofunctional } \\
\text { properties. }\end{array}$ & \multirow{3}{*}{$\begin{array}{l}\text { In dairy industry whey is a by-product during the manufacture of coagulated milk } \\
\text { products such as paneer, channa, casein etc. Bioactive peptides produced by the } \\
\text { fermentation of the whey have various biofunctional properties. The ACE inhibitory } \\
\text { activity of cultured buttermilk prepared by addition of } 40 \% \text { fermented whey }\left(\mathrm{RT}_{3}\right) \text {, } \\
30 \% \text { fermented whey }\left(\mathrm{RT}_{4}\right) \text { and control }\left(\mathrm{RT}_{5}\right) \text { were found to be } 69.24,64.50 \text { and } \\
57.63 \text { per cent respectively. The antioxidant activity of cultured buttermilk as } \\
\text { determined by ABTS method were } 54.58\left(\mathrm{RT}_{3}\right), 47.59\left(\mathrm{RT}_{3}\right) \text { and } 41.57 \text { per cent }\left(\mathrm{RT}_{5}\right) \text {. } \\
\text { The antimicrobial studies showed that the zone of inhibition by } \mathrm{RT}_{3}, \mathrm{RT}_{4} \text { and } \mathrm{RT}_{5} \\
\text { against } S \text {. aureus were } 2.23,2.00 \text { and } 0.32 \mathrm{~mm} \text {; and it was } 2.81,2.20 \text { and } 1.28 \mathrm{~mm} \\
\text { respectively against } E \text {. coli while thee inhibition zone against } S \text {. thyphi by } \mathrm{RT}_{3}, \mathrm{RT}_{4} \\
\text { and } \mathrm{RT}_{5} \text { were } 2.60,2.10 \text { and } 0.82 \text { mm respectively. Incorporation of fermented paner } \\
\text { whey significantly improved the biofunctional properties of cultured buttermilk. }\end{array}$} \\
\hline Article Info & \\
\hline $\begin{array}{l}\text { Accepted: } \\
\text { 20 January } 2017 \\
\text { Available Online: } \\
\text { 10 February } 2017\end{array}$ & \\
\hline
\end{tabular}

\section{Introduction}

Fermentation of milk enhances its nutritional value through improved bioavailability of nutrients and production of bioactive substances which have biological functions. Cultured buttermilk, it is an important fermented milk in the world. It is obtained from pasteurized skim or partly skim milk cultured with Lactococci and Lactobacilli as well as aroma producing strains. Lactic acid bacteria (LAB) are able to produce bioactive peptides during milk fermentation (Nielsen, 2009). Looking to composition and characteristics of paneer whey, particularly its acidic nature and salty taste, the most appropriate product from among different dairy products for utilization of the this whey is cultured buttermilk. Whey produces high amounts of bioactive peptides when it gets fermented (Canli, 2005). In the present study, fresh samples of cultured buttermilk were analyzed for their selected biofunctional properties like ACE inhibitory, proteolytic, antioxidant and antimicrobial activities.

ACE is a peptidyl di-peptidase enzyme having the capacity to cleave the carboxyl terminal end of the substrate that may regulate an increase in blood pressure by converting angiotensin I to an active peptide hormone angiotensin II (Korhonen and Pihlanto, 2009). 
In case of antioxidant activity, Whey might also enhance antioxidant capacity by contributing cysteine rich proteins which are pivotal in the synthesis of glutathione, a major intracellular antioxidant (Ha et al., 2003). Several milk peptides also play a regulatory role in oxidative metabolism which is essential for the survival of cells and causes oxidative changes by producing free radicals. Several antimicrobial components which are present in the whey like lactoferrin, immunoglobulins, lysozymes and lactoperoxides produces antimicrobial effects in the products (Marshall, 2004).

\section{Materials and Methods}

\section{Preparation of cultured buttermilk using paneer whey}

For the present study the desired strain of lactic acid bacteria (Lactococcus lactis subspp. Diacetylactis NCDC 60) was collected from National Collections of Dairy Cultures (NCDC), Dairy Microbiology Division, NDRI, Karnal and Lactobacillus helveticus MTCC 5463 strain was collected from Microbial Type Culture Collection (MTCC), Department of Dairy Microbiology, AAU, Anand. Both the cultures were maintained in skim milk at $4^{\circ} \mathrm{C}$ in test tube. The strain was subcultured at $37^{\circ} \mathrm{C}$ for $24 \mathrm{~h}$ in skim milk media before being use for any experiment. The growth of the organism was determined by counting $\mathrm{CFU}$ after plating serial dilutions on MRS agar (for L. helveticus MTCC 5463) and M17 agar (for L. Lactis subspp. Diacetylactis NCDC 60) after incubation at $37^{\circ} \mathrm{C}$ for $48 \mathrm{~h}$. In case of combination of both the cultures lactic agar was used to enumeration of lactococci and lactobacilli counts (Parekh et al., 2016).

Cultured buttermilk was prepared according to the method described by Ghanshyambhai et al., (2015). Fresh paneer was prepared by laboratory method and whey was collected. The whey and double toned milk were heated to $90^{\circ} \mathrm{C}$ for 5 min to kill the all living bacteria and cooled to $37^{\circ} \mathrm{C}$. The whey and milk were inoculated with $L b$. helveticus MTCC 5463and L. lactis sub spp. Diacetylactis NCDC 60 at the rate 2 per cent (1:1) and incubated at $37^{\circ} \mathrm{C}$ for $48 \mathrm{~h}$. The fermented whey and dahi were mixed in to the two different ratios 60:40 $\left(\mathrm{RT}_{3}\right), 70: 30\left(\mathrm{RT}_{4}\right)$ and control $\left(\mathrm{RT}_{5}\right)$ was prepared by using water in case of fermented whey in 70:30 $\mathrm{RT}_{5}$ (dahi:water) ratio. All the samples were analyzed for its selected biofunctional properties like ACE inhibitory, proteolytic, antioxidative and antimicrobial activity.

\section{Determination of ACE inhibitory activity}

For measuring the ACE inhibitory activity, Angiotensin I- converting enzyme (ACE) from rabbit lung, N-Hippuryl-His-Leu hydrate (HHL) and 2, 2'-Azino-bis (3ethylbenzothaizoline-6-sulfonic acid) (ABTS) chemicals were purchased from SigmaAldrich Inc., India.

The ACE-inhibitory activity percentage (ACEi \%) was determined according to the method described by Cushman and Cheung (1971) with some modifications (Hati et al., 2015) as described below. This method is based on the reaction of hydrolysis of $\mathrm{N}$ Hippuryl-His-Leu (HHL) into hippuric acid (HA) and His-Leu (HL) catalysed by the ACE. The activity of ACE was measured in terms of HA produced over time. The fermented milk samples were defrosted at room temperature $\left(20^{\circ} \mathrm{C}\right)$ for $15 \mathrm{~min}$. An aliquot of $10 \mu \mathrm{l}$ of fermented milk sample was added to $30 \mu \mathrm{l}$ of ACE $(60 \mathrm{mU} / \mathrm{ml})$ and then incubated for $10 \mathrm{~min}$ at $37^{\circ} \mathrm{C}$ in $2 \mathrm{ml}$ tubes, before $90 \mu \mathrm{l} 5 \mathrm{mM}$ HHL was added. The mixture was gently stirred and then incubated at $37^{\circ} \mathrm{C}$ for $60 \mathrm{~min}$. The reaction was stopped by adding $8 \mu \mathrm{l}$ of $5 \mathrm{M} \mathrm{HCl}$ and the samples 
were filtered through sterile filters of 0.20 $\mathrm{mm}$ pore size. The absorbance was measured spectrophotometrically using Systronic Double beam Spectrophotometer 2202, India at $250 \mathrm{~nm}$ against blank. For blank, all components except ACE (i.e. HHL, borate buffer and distilled water) were used.

The $\mathrm{ACE}_{\mathrm{i}} \%$ was calculated by subtracting the HA produced in the presence of the inhibitors to the HA produced in absence of inhibitors (under the same conditions) as shown below:

$$
\begin{aligned}
& \text { Absorbance of } \mathrm{HA}_{\text {control }} \text { - Absorbance of HA } \\
& \text { ACE }_{\mathrm{i}} \%=\longrightarrow \times 100
\end{aligned}
$$$$
\text { Absorbance of HA control }
$$

Where, HA control is the concentration of hippuric acid produced by the ACE incubated in milk at $37^{\circ} \mathrm{C}$ without inoculums (unfermented milk and whey in selected ratio). This control was found to be more appropriate for this study than buffer as it reduced any interference from other components in the milk such as calcium that may induce inhibition. It was also found that these effects varied with time necessitating to select milk supernatants with no inoculum treated at $37^{\circ} \mathrm{C}$ and at different times as control. HA sample is the concentration of hippuric acid produced by the ACE in the presence of inhibitors contained in the fermented milk.

\section{Determination of proteolytic activity}

For measuring the proteolytic activity, trichloroacetic acid (TCA) and OPA (Ophthaldialdehyde) was used.

$$
\% \text { Inhibition (ABTS method) }=\frac{\text { Blank - Sample }}{\text { Blank }}
$$

Proteolytic activity was measured by OPA (O-phthaldialdehyde) method (Quantitative method) described by Hati et al., (2015).An aliquot of $2.5 \mathrm{ml}$ of activated cultures was added to $5 \mathrm{ml}$ of 0.75 per cent trichloroacetic acid (TCA) and allowed to stand for $10 \mathrm{~min}$ and the mixture was filtered using Whatman filter paper no. 42. Then $150 \mu$ of filtrate obtained from filtration process was transferred to $3 \mathrm{ml}$ of OPA reagent and mixed properly. After incubation for $2 \mathrm{~min}$ at room temperature, the absorbance of solution was measured spectrophotometrically at $340 \mathrm{~nm}$. The proteolytic activities of bacterial cultures were expressed as absorbance of free amino acid groups measured at $340 \mathrm{~nm}$.

\section{Determination of antioxidant activity}

For measuring the antioxidant activity, ABTS 2, 2'-Azino-bis (3-ethylbenzothaizoline -6sulfonic acid), potassium persulphate and phosphate buffer saline (PBS) were used.

Antioxidant activity was measured by using ABTS 2, 2'-Azino-bis (3ethylbenzothaizoline -6-sulfonic acid) Assay method. Total radical scavenging capacity was based on the ability of a compound to scavenge the stable ABTS radical in $10 \mathrm{~min}$ (Re et al., 1999) with some modifications. The ABTS working solution was prepared by mixing $88 \mu \mathrm{l}$ of $140 \mathrm{mM}$ potassium persulphate with $5 \mathrm{ml}$ of $7 \mathrm{mM}$ ABTS stock solution and incubating overnight in dark bottles for generation of radicals. Then it was diluted with phosphate buffer saline (PBS) to adjust the absorbance at $734 \mathrm{~nm}$ to $0.7 \pm 0.02$. An aliquot of $10 \mu \mathrm{l}$ of product supernatant collected after centrifuging at $14000 \mathrm{rpm}$ for 30 min was coated in 96 wells microplate and to this $100 \mu \mathrm{l}$ ABTS in PBS solution was added and mixed for $10 \mathrm{~s}$. The decrease in absorbance at $734 \mathrm{~nm}$ was recorded over a period of $10 \mathrm{~min}$ at $10 \mathrm{sec}$ interval using spectrophotometer.

Where, for blank, unfermented milk and whey were used in selected ratios. 


\section{Determination of antimicrobial activity}

Activity of the culture filtrate was tested by the agar well method (Delgado et al., 2001) with some modifications against Escherichia coli, Salmonella typhi and Staphylococcus aureus (indicator strains obtained from Department of Dairy Microbiology, S.M.C. College of Dairy Science, Anand). The method is based on the principle that involves the ability of one microorganism to inhibit the growth of another, as exhibited by clear zone of inhibition.

Fifteen to twenty $\mathrm{ml}$ of nutrient agar were poured in to the Petri dishes and allowed to solidify. Then the indicator strains were applied over the solidified agar medium by using spreader and allowed to dry or the plates were refrigerated at $5^{\circ} \mathrm{C}$ for $10-15 \mathrm{~min}$ before several wells were punched out of the agar with sterile borer (Himedia, diameter-15 $\mathrm{mm})$.

Buttermilk samples were then filled into the wells to check their inhibition activities on four indicators (E. coli, S. typhi and $S$. aureus). The plates were once again refrigerated at $5^{\circ} \mathrm{C}$ for 10 to $15 \mathrm{~min}$ to facilitate the diffusion of buttermilk and were incubated at $37^{\circ} \mathrm{C}$ for 24 to $48 \mathrm{~h}$. The inhibition activities of the culture filtrates of the $\mathrm{LAB}$ isolates on the indicator bacteria were indicated by the presence of a clear zone surrounding the agar wells.

The zone of inhibition around the wells was measured in $\mathrm{mm}$.

\section{Statistical analysis}

The data obtained during the present investigation were analyzed by Completely Randomized Design (CRD) (Steel and Torrie, 1980) with equal number of observation.

\section{Results and Discussion}

The cultured buttermilk prepared by the incorporation of fermented panner whey in to dahi (as per the method standardized by Ghanshyambhai et al., (2015) gave acceptable sensory qualities with all sensory scores i.e. flavor, body and texture, colour and appearance and overall acceptability above 7.5 on 9 - point hedonic scale.

\section{ACE inhibitory activity}

ACE inhibitory and proteolytic activity of buttermilk was determined as method described in methods and materials. ACE inhibitory activity of cultured buttermilk (addition of fermented whey in two different concentrations 60:40 $\left(\mathrm{RT}_{3}\right), 70: 30\left(\mathrm{RT}_{4}\right)$ with control $\left.\left(\mathrm{RT}_{5}\right)\right)$ is presented in table 1 .

The examination of data shows that the average values for ACE inhibitory activity of cultured buttermilk $\mathrm{RT}_{3}, \mathrm{RT}_{4}$ and control $\left(\mathrm{RT}_{5}\right)$ was found to be $69.24,64.50$ and 57.63 per cent respectively. The ACE-inhibitory activity of buttermilk samples $\left(\mathrm{RT}_{3}\right)$ was highest due to higher amounts of bioactive peptides present in the products as it contained higher amount of fermented paneer whey than other samples. The difference in the ACE inhibitory activity among $\mathrm{RT}_{3}, \mathrm{RT}_{4}$ andRT $\mathrm{T}_{5}$ was statistically significant $(\mathrm{P}<0.05)$.

ACE inhibitors are di- or tri-peptides containing proline, lysine or arginine at their $\mathrm{C}$ terminal end. Bioactive amino acid sequence displaying antihypertensive activity is mainly isolated from bovine and human caseins. Whey proteins derived by the activity of lactic acid bacteria like $L$. helveticus, $L$. lactis are resistant to the digestive tract endopeptidases, therefore, can be easily absorbed to the blood stream. ACE inhibitor peptides are food derived natural preventives used to control hypertension and could lead to 
a decrease in the requirement of medicines which exert strong side effects (Korhonen and Pihlanto, 2009).

Hati et al., (2015) evaluated ACE-inhibitory activities of eight different cultures. They found that $L b$. rhamnosus (NS4) and $L b$. delbruckii (009) showed maximum activity 79.66 and 67.09 per cent respectively compared to other isolates. They also suggested that Lb. helveticus MTCC 5463 (V3) and Lb. Delbruckii (009) also has ACE inhibitory activities and produced highest proteolytic zone in skim milk agar plate under optimized growth.

Sun et al., (2009) reported that the Lactobacillus ND 01 (69.01 per cent) strain produces both the high ACE-inhibitory activity and gamma aminobutyric acid (GABA). They identified Lactobacillus ND 01 as one strain of L. helveticus and suggested that it showed good potential for application in the management of hypertension. They found that milks fermented by several strains of L. helveticus showed antihypertensive activity, and ACE inhibitory peptides (ValPro-Pro and Ile-Pro-Pro) were identified from the fermented milk by L. helveticus.

Conway et al., (2014 a, b) studied the effect of buttermilk consumption on blood pressure in moderately hypercholesterolemic men and women. They found that milk fat globule membrane (MFGM) present in buttermilk is rich in unique bioactive proteins and concluded that short term supplementation with buttermilk (45 g/d) possibly through its high MFGM content and its effect on the ACE system lowers systolic blood pressure in normotensive individuals and combined with the buttermilk induced reduction in plasma levels of total cholesterol and triglycerides (TGs) in the same individuals. They suggested that buttermilk may represent a new safe food modality to manage blood cholesterol and blood pressure as part of healthy eating.

Fuglsang et al., (2003) reported that Lb. helveticus has been the preferred fermenting organism in the pursuit of an effective ACEinhibitory milk product due to its generally higher proteolytic activity compared to other LAB, but also because of the high activity of the derived peptides.

Kapila et al., (2009) evaluated the biofunctional properties of fermented whey protein hydrolysates. They optimized the parameters according to the peptides production, ACE-inhibitory activity and analysed ACE-inhibition by fermenting whey and whey supplemented with whey protein concentrate (WPC) with Lactobacillus helveticus NCDC 292 (1 per cent, $37^{\circ} \mathrm{C} / 48 \mathrm{~h}$ ) under in vitro conditions. They observed that ACE-inhibitory activity of whey and fermented whey was 13.33 and 59.86 per cent respectively under in vitro condition.

Mohanty et al., (2015) stated that bioactive peptides were released from milk proteins by various microorganisms during fermentation. They found that fermentation of milk by $L b$. helveticus released Val-Pro-Pro (VPP) and Ile-Pro-Pro (IPP) peptides which had ACEinhibitory activity. They also reported that fermentation with Lb. helveticus CP90 proteinase released Lys-Val-Leu-Pro-ValPro-(Glu) peptides gave the ACE-inhibitory effect.

The ACE inhibitory activity of cultured buttermilk samples were in accordance with the reported literature. From above literature, it is evident that peptides produced by fermentation of whey proteins possess ACE inhibitory activity also the $L b$. helveticus strain exhibits good ACE inhibitory activity. The cultured buttermilks $\mathrm{RT}_{3}$ and $\mathrm{RT}_{4}$ were prepared by blending dahi and fermented 
whey in 60:40 and 70:30 (w/w) proportions. Mixed culture of $L b$. helveticus NCDC 5463 and L. Lactis subspp. diacetylactis NCDC 60 was used for fermentation. Both these factors have contributed to the good ACE inhibitory activity of $\mathrm{RT}_{3}$ and $\mathrm{RT}_{4}$. Even though the same culture was used in case of control sample its ACE inhibitory activity was much less compared to $\mathrm{RT}_{3}$ and $\mathrm{RT}_{4}$ because it contained no fermented whey.

Thus, it can be stated that incorporation of fermented whey improved ACE inhibitory activity of cultured buttermilk compared to control (prepared by conventional method).

\section{Antioxidant activity}

Antioxidant activity of buttermilk was determined as method described in methods and materials. Antioxidant activity of cultured buttermilk (addition of fermented whey in two different concentrations 60:40 $\left(\mathrm{RT}_{3}\right)$, 70:30 $\left(\mathrm{RT}_{4}\right)$ with control $\left.\left(\mathrm{RT}_{5}\right)\right)$ is presented in table 2 .

The examination of data shows that the average values for antioxidant activity of cultured buttermilk obtained with the addition of fermented paneer whey $\mathrm{RT}_{3}$ and $\mathrm{RT}_{4}$ was found to be 54.58 and 47.59 per cent while that of control sample $\mathrm{RT}_{5}$ was 41.57 per cent.

The antioxidant activity of buttermilk samples $\left(\mathrm{RT}_{3}\right)$ was highest due to higher amounts of bioactive peptides present in the products as contained higher amount of fermented paneer whey than other samples; the bioactive peptides had higher free radical scavenging activity. The difference in the antioxidant activity among $\mathrm{RT}_{3}, \mathrm{RT}_{4}$ and $\mathrm{RT}_{5}$ was statistically significant $(\mathrm{P}<0.05)$.

Lactoferrin and lactoferricin, two minor proteins in whey $(0.1 \mathrm{~g} / \mathrm{l})$, function as antioxidants due to their iron binding capacity. Lactoferrin is only 8-30 per cent saturated in its native state, a condition that enables chelation of iron and subsequent inhibition of bacterial growth or oxidative reactions. Whey might also enhance antioxidant capacity by contributing cysteine rich proteins which are pivotal in the synthesis of glutathione, a major intracellular antioxidant (Ha et al., 2003).

Several milk peptides also play a regulatory role in oxidative metabolism, which is essential for the survival of cells and causes oxidative changes by producing free radicals. But when an excess of free radicals is released, they oxidize cellular protein, membrane lipid, DNA, and enzymes that cause shutting down of cellular respiration and mediate injuries including atherosclerosis, diabetes, rheumatoid arthritis and oxidative DNA-damage leading to cancer (Abuja and Albertini, 2001; Halliwell, 2000; Halliwell and Whiteman, 2004).

Moreover, milk-derived anti-oxidative peptides are comprised of five to eleven hydrophobic amino acids including proline, histidine, tyrosine or tryptophan in sequence which are widely distributed among caseins, soybean and gelatine in hydrolysis by proteolytic enzymes (Korhonen and Pihlanto, 2009).

Kapila et al., (2009) evaluated the biofunctional properties of fermented whey protein hydrolysates. They optimized the parameters according to the peptide production, antioxidative activity by fermenting whey and whey supplemented with whey protein concentrate (WPC) with Lactobacillus helveticus NCDC 292 (1 per cent, $\left.37^{\circ} \mathrm{C} / 48 \mathrm{~h}\right)$. They observed that fermented whey protein hydrolysate showed good antioxidative activity under in vitro conditions. 
Shah (2011) found the activity of combination of $L$. helveticus MTCC 5463 and $S$. thermophilus MTCC 5460 by hydroxy radical scavenging activity of intact and intracellular extracts as 102.27 and 164.46 per cent, respectively, whereas 1.70 and 6.48 by DPPH and 5.46 and 2.47 per cent by ABTS method.

Conway et al., (2013) studied the antioxidant activities of buttermilk proteins, whey proteins, and their enzymatic hydrolysates. They compared oxygen radical absorbance capacities (ORAC) and metal chelating capacities (MCC) of protein concentrates which was prepared from buttermilk and cheese whey by ultrafiltration with those of skim milk protein. They found that the highest MCC was obtained for hydrolyzed skim milk protein and ORAC values varying from 554.4 to $1319.6 \mu \mathrm{mol}$ Trolox equivalents/g proteins, with the highest value obtained for hydrolyzed buttermilk protein. They showed that peptides derived from milk fat globule membrane proteins, primarily butyrophilin, could be responsible for the superior antioxidant activity of buttermilk and finally they suggested that hydrolyzed buttermilk protein could be used as a source of natural antioxidants.

Wong and Kitts (2003) stated that buttermilk solids were also demonstrated to possess antioxidant activity and have been suggested for use in stabilizing food matrixes against lipid peroxidation reaction.

Kapila et al., (2009) evaluated the antioxidative activity of whey and whey supplemented with whey protein concentrate (WPC) fermented by Lactobacillus helveticus NCDC 292 ( 1 per cent, $\left.37^{\circ} \mathrm{C} / 48 \mathrm{~h}\right)$ under in vitro conditions. There was significant $(\mathrm{p}<0.001)$ rise in antioxidative activity on fermentation with $L$. helveticus. This increase was nearly 4 fold in both the hydrolysates in comparison to unfermented products.
Thompkinson and Mathur (1989) attributed the observed antioxidant activity of buttermilk solids to the presence of phospholipids, and associated activity in donating a proton to a free radical or by the sequestering of iron. Alternatively, the sulfhydryl groups in processed dairy products may also be presumably associated with antioxidant activity (Jocelyn, 1972; Chow, 1979; Taylor and Richardson, 1980).

It is well evident from literature that fermented whey possess antioxidant activity. Also various research workers have established antioxidant activities of $L b$. helveticus MTCC 5463, which is evident from the higher antioxidant potential of $\mathrm{RT}_{3}$ and $\mathrm{RT}_{4}$ compared to control. Even though the same culture was used in case of control sample, its antioxidant activity was much less compared to $\mathrm{RT}_{3}$ and $\mathrm{RT}_{4}$ as it did not contain fermented whey which contributed bioactive peptides. Proper blending of dahi with fermented whey also resulted in the release of phospholipids due to churning effect and hence its presence in all the three types of cultured buttermilk. The peptides derived from milk fat globule membrane proteins, primarily butyrophilin, could be also responsible for the superior antioxidant activity of buttermilk. Thus, it can be stated that incorporation of fermented whey improved antioxidant potential of cultured buttermilk.

\section{Antimicrobial activity}

Antimicrobial activity of buttermilk were determined as method described in methods and materials. Antimicrobial activity of cultured buttermilk (addition of fermented whey in two different concentration 60:40 $\left(\mathrm{RT}_{3}\right)$, 70:30 ( $\left.\mathrm{RT}_{4}\right)$ with control $\left.\left(\mathrm{RT}_{5}\right)\right)$ is presented in table 3 .

The examination of data shows that the zones of inhibition by RT3, RT4 and RT5 against S. 
aureus were $2.23,2.00$ and $0.32 \mathrm{~mm}$; and it was $2.81,2.20$ and $1.28 \mathrm{~mm}$ respectively against $E$.coli. The inhibition zone against $S$. thyphi by $\mathrm{RT}_{3}, \mathrm{RT}_{4}$ andRT $\mathrm{R}_{5}$ were $2.60,2.10$ and $0.82 \mathrm{~mm}$, respectively. The antimicrobial activity of the sample $\mathrm{RT}_{3}$ was higher than $\mathrm{RT}_{4}$ as it has higher amount of fermented paneer whey (40 per cent) compared to the later. The antimicrobial activity of control sample $\mathrm{RT}_{5}$ preapared by blending dahi and water in 70:30 proportions (w/w) was much less than that of cultured buttermilk samples containing fermented paneer whey. The difference in the antimicrobial activity among $\mathrm{RT}_{3}, \mathrm{RT}_{4}$ and $\mathrm{RT}_{5}$ was statistically significant $(\mathrm{P}<0.05)$. Thus, it is very clear that addition of fermented paneer whey increased antimicrobial activity of cultured buttermilk.

Milk components impart antimicrobial potential, for example, milk is rich source of immunoglobulins present in colostrum and provides immunity against various infections resist pathogens to colonize in intestinal epithelia, reduce absorption of food antigens and promotes phagocytosis of pathogens (Walzem, 2001). In addition, lactoferrin, a whey protein that has strong affinity for iron present in milk, removes freely present iron and renders it unavailable for most of the pathogenic enzymes and proteins to function properly.

Another important defensive component of milk is lysozyme, which hydrolyzes the peptidoglycan subunits of pathogens cell wall. Besides, lactoperoxidase of milk reacts with microorganism derived hydrogen peroxide and generates some highly reactive intermediary compounds that have cell wall degrading potential of invading microorganisms (Marshall, 2004).

Antimicrobial bioactive peptides derived from milk have been reported to inhibit many Gram positive and Gram negative pathogens including Escherichia coli MTCC 82, Aeromonas hydrophila ATCC7966, Salmonella typhi MTCC 3216, Bacillus cereus ATCC10702, Salmonella typhimurium SB 300, S. enteritidis 125109, St. aureus MTCC 96 (Mohanty et al., 2014) and control many microbial infections.

Many workers reported that lactoferrin and its derivatives show the antibacterial activity in vitro against various pathogens, e.g. Clostridium perfringens, $C$. albicans, Haemophilus influenzae, Helicobacter pylori, L. monocytogenes, $P$. aeruginosa, Salmonella enteritidis, S. aureus, Vibrio choleraeas well as antiviral activity against hepatitis $\mathrm{C}, \mathrm{G}$ and $B$ virus HIV-1, poliovirus, rotavirus and herpes simplex virus (Farnaudu and Evans, 2003; Pan et al., 2007).

Bhardwaj and Singh (2013) demonstrated that bioactive peptides generated during fermentation with $L$. helveticus showed a good degree of inhibition including zone of inhibition $17 \mathrm{~mm}$ against Gram's negative bacteria and $15 \mathrm{~mm}$ for Gram's positive bacteria at $5.1 \mathrm{pH}$ for 20 hours of incubation and combination of Lactococcus and Lactobacilli at 4 per cent inoculation showed a good degree of inhibition zone $15.6 \mathrm{~mm}$ against Gram's positive bacteria and $12 \mathrm{~mm}$ for Gram's negative bacterial when kept at $3.2 \mathrm{pH}$ for 28 hours of incubation. They suggested that the acitimicobial acitivity was found higher with the $L b$. heleveticus in comparison to the combination of Lactococcus and Lactobacilli.

The Lb. helveticus MTCC 5463 strain was isolated from the vaginal tract of healthy adult female in India at Anand Agricultural University (Khedkar et al., 1991). The strain exhibited significant antimicrobial activity against Bacillus cereus, Staphylococcus aureus, Pseudomonas aeruginosa, Salmonella typhi and Escherichia coli. 
Buttermilk contains more phospholipids than milk because of its high content in MFGM material, which is rich in phospholipids that constitute about one-third of the MFGM (Mulder and Walstra, 1974). Christie et al., (1987) determined a 4-fold increase of phospholipids in buttermilk compared with whole milk, with a phospholipid content of $0.72 \mathrm{mg} / \mathrm{ml}$ and $0.15 \mathrm{mg} / \mathrm{ml}$, respectively.
Phospholipids have been shown to possess biological activity. Some studies have demonstrated the anticarcinogenic potential of phospholipids, especially against colon cancer (Dillehay et al., 1994; Schmelz et al., 1996, 1998), as well as their protective effect against bacterial toxins and infection (Rueda et al., 1998; Sprong et al., 2002).

Table.1 ACE inhibitory and Proteolytic activity of cultured buttermilk

\begin{tabular}{|c|c|c|}
\hline Types of buttermilk & $\begin{array}{c}\text { ACE inhibitory activity } \\
(\mathrm{ACEi} \%)\end{array}$ & $\begin{array}{l}\text { Proteolytic activity } \\
\text { (absorbance at } 340 \mathrm{~nm} \text { ) }\end{array}$ \\
\hline $\mathrm{RT}_{3}(60: 40)$ & $69.24^{\mathrm{a}}$ & $0.638^{\mathrm{c}}$ \\
\hline $\mathrm{RT}_{4}(\mathbf{7 0 : 3 0 )}$ & $64.50^{b}$ & $0.596^{\mathrm{b}}$ \\
\hline $\mathrm{RT}_{5}$ (control) & $57.63^{c}$ & $0.421^{\mathrm{a}}$ \\
\hline SEm \pm & 0.37 & 0.003 \\
\hline CD & 1.14 & 0.010 \\
\hline $\mathrm{CV} \%$ & 1.28 & 1.34 \\
\hline \multicolumn{3}{|c|}{$\begin{array}{l}* \text { First digit in the ratio stands for per cent of dahi and second digit for per cent of fermented } \\
\text { paneer whey on w/w basis. } \\
\mathrm{RT}_{5} \text { : Control (dahi: water in } 70: 30 \mathrm{w} / \mathrm{w} \text { ratio) } \\
\text { \#The values are mean of five replications. } \\
* * * \text { Values within columns (treatments) with same lowercase superscript did not differ } \\
\text { significantly }(\mathrm{P}<0.05) \text { from each other. }\end{array}$} \\
\hline
\end{tabular}

Table.2 Antioxidant activity of cultured buttermilk

\begin{tabular}{|c|c|}
\hline Types of buttermilk & Antioxidant activity (\% inhibition) by ABTS method \\
\hline $\mathrm{RT}_{3}(60: 40)$ & $54.58^{\mathrm{a}}$ \\
\hline $\mathrm{RT}_{4}(\mathbf{7 0 : 3 0 )}$ & $47.59^{b}$ \\
\hline $\mathrm{RT}_{5}$ (control) & $41.57^{\mathrm{c}}$ \\
\hline SEm \pm & 0.22 \\
\hline CD & 0.67 \\
\hline CV \% & 1.01 \\
\hline \multicolumn{2}{|c|}{$\begin{array}{l}\text { * First digit in the ratio stands for per cent of dahi and second digit for per cent of fermented } \\
\text { paneer whey on w/w basis. } \\
\text { RT }_{5} \text { : Control (dahi: water in } 70: 30 \mathrm{w} / \mathrm{w} \text { ratio) } \\
\text { \#The values are mean of five replications. }\end{array}$} \\
\hline
\end{tabular}


Table.3 Antimicrobial activity of cultured buttermilk

\begin{tabular}{|c|c|c|c|}
\hline \multirow{2}{*}{$\begin{array}{c}\text { Types of } \\
\text { buttermilk }\end{array}$} & \multicolumn{3}{|c|}{ Antimicrobial activity (Zone of inhibition in $\mathrm{mm}$ ) } \\
\hline & S. aureus & E. coli & S. thyphi \\
\hline $\mathrm{RT}_{3}(60: 40)$ & $2.23^{\mathrm{a}}$ & $2.81^{\mathrm{a}}$ & $2.60^{\mathrm{a}}$ \\
\hline $\mathrm{RT}_{4}(\mathbf{7 0 : 3 0 )}$ & $2.00^{b}$ & $2.20^{\mathrm{b}}$ & $2.10^{b}$ \\
\hline $\mathbf{R T}_{5}$ (control) & $0.32^{\mathrm{c}}$ & $1.28^{\mathrm{c}}$ & $0.82^{\mathrm{c}}$ \\
\hline SEm \pm & 0.03 & 0.04 & 0.04 \\
\hline CD & 0.08 & 0.12 & 0.11 \\
\hline $\mathrm{CV} \%$ & 3.71 & 3.98 & 4.38 \\
\hline \multicolumn{4}{|c|}{$\begin{array}{l}\text { * First digit in the ration stands for per cent of dahi and second digit for per cent of fermented } \\
\text { paneer whey on w/w basis. } \\
* * \text { Borer diameter was } 15 \mathrm{~mm} \text { which is exclude from the total diameter measured. } \\
\mathrm{RT}_{5} \text { : Control (dahi: water in } 70: 30 \mathrm{w} / \mathrm{w} \text { ratio) } \\
\text { \#The values are mean of five replications. }\end{array}$} \\
\hline
\end{tabular}

The antimicrobial activity of $\mathrm{RT}_{3}$ and $\mathrm{RT}_{4}$ prepared by blending dahi with fermented paneer whey in 40 and 30 per cent, respectively had significant higher antimicrobial activity against selected pathogens compared to the control $\mathrm{RT}_{5}$ (containing 70 per cent dahi with 30 per cent water). This can be attributed to the presence of antimicrobial bioactive peptides derived from fermented whey. Lactoferrin and immunoglobulin, the whey protein fractions, also have contributed to antimicrobial activity of $\mathrm{RT}_{3}$ and $\mathrm{RT}_{4}$ compared to $\mathrm{RT}_{5}$. Other major components with antimicrobial activity like phospholipids were common in three types of cultured buttermilk under study.

The whey protein (about $20 \%$ of the total milk protein) represents a rich source of biologically active molecules that are able to influence a range of physiological functions such as its role in uptake of trace elements and vitamins.

Whey protein in their native form is fragmented into smaller peptides in our digestive system, which in turn exhibit biological activities in different physiological systems. Whey fermented with LAB starters is enriched with a high level of peptides than original whey; the actual figure depends upon the proteolytic potential of the strain used. Such peptides have different functions in vitro as well as in vivo for example antihypertensive, antimicrobial, anti-oxidative, anti-thrombotic, mineral-carrying and opioid, immunomodulation, etc. effects.

In conclusion, the analysis of cultured buttermilk for its selected biofunctional properties revealed that both the $\mathrm{RT}_{3}$ (prepared by blending 60 per cent dahi and 40 per cent fermented paneer whey) and $\mathrm{RT}_{4}$ (prepared by blending 70 per cent dahi and 30 per cent fermented paneer whey) have good ACE inhibitory activity, antioxidant potential and antimicrobial properties compared to control sample $\mathrm{RT}_{5}$ (prepared by blending 70 per cent dahi and 30 water). But in comparison to $\mathrm{RT}_{4}$, cultured buttermilk $\mathrm{RT}_{3}$ has significantly higher biofunctional properties that were studied. This is due the presence of higher proportion of fermented paneer whey in $\mathrm{RT}_{3}$ cultured buttermilk. 
Incorporation of fermented paneer whey in the preparation of cultured buttermilk provided a practical and commercial application for utilization of paneer whey, a major by product in most of dairy plants. It is revealed from the present study that the incorporation of fermented paneer whey significantly improved the biofunctional properties of cultured buttermilk.

Thus, it can be inferred that incorporation of fermented paneer whey in the preparation of cultured buttermilk enhanced its biofunctional properties in addition to providing a method for utilization of paneer whey.

\section{References}

Abuja, P. and Albertini, R. 2001. Methods for monitoring oxidative stress, lipid peroxidation and oxidation resistance of lipoproteins. Clin. Chim. Acta., 306:1-17.

Bhardwaj, G. and Singh, B. 2013. Optimization of conditions for production of bioactive peptides showing antimicrobial effect on bacterial pathogens during fermentation of bovine milk with LAB. Int. J. Cell Sci. Biotecnol., 2:11-14.

Canli, O. 2005. Physico-chemical treatment of cheese whey effluent. M.Sc. thesis submitted to DokuzEylul University, Izmir., 1-2.

Christie, W.W., Noble, R.C. and Davies, G. 1987. Phospholipids in milk and dairy products. J. Soc. Dairy Technol., 40:1012.

Conway, V., Couture, P., Gauthier, S., Pouliot, Y., and Lamarche, B. 2014a. Effect of buttermilk consumption on blood pressure in moderately hypercholesterolemic men and women. Nutrition., 30: 116-119.

Conway, V., Gauthier, S.F, and Pouliot, Y. 2014b. Buttermilk: Much more than a source of milk phospholipids. Animal Frontiers., 4: 44-51.

Conway, V., Gauthier, S.F., and Pouliot, Y. 2013. Antioxidant activities of buttermilk proteins, whey proteins, and their enzymatic hydroly sates. J. of Agricul. and Food Chem., 61(2): 64-72.

Cushman, D.W., and Cheung, H.S. 1971. Spectrophotometric assay and properties of the angiotensin-converting enzyme of rabbit lung. Biochem. Pharmacol., 20: 1637-1648.

Delgado, A., Brito, D. and Fevereiro, P. 2001. Antimicrobial activity of $L$. plantarumisolated from a traditional lactic acid fermentation of tableolives. EDP Sci., 81: 203-215.

Dillehay, D.L., Webb, S.J., Schmelz, E.M. and Merill, A.H. 1994. Dietary sphingomyelin inhibits 1,2-dimethylhydrazine-induced colon cancer in CF1 mice. J. Nutr., 124: 615-620.

Farnadu, S. and Evans, R.W. 2003. Lactoferrina multifunctional protein with antimicrobial properties. Mol. Immunol., 40:395-405.

Fuglsang, A., Rattray, F.P., Nilsson, D., Nyborg, N.C.B. 2003. Lactic acid bacteria: inhibition of angiotensin converting enzymes invitro and in vivo, Antonie Leeuwenhoek., 83: 27-34.

Ghanshyambhai, M.R., Balakrishnan, S., and Aparnathi, K.D. 2014. Standardization of the method for utilization of paneer whey in cultured buttermilk. J. Food Sci. and Technol., doi:10.1007/s13197-014-13012.

Ha, S., Leng, A.M.G., and Mang, L. 2003. Koumiss and its medicinal values. China J. Chinese Material Medica, 28:11-14.

Halliwell, B. 2000. Lipid peroxidation, antioxidants and cardiovascular disease: how should we move forward? Cardiovasc. Res., 47: 410-418.

Halliwell, B. and Whiteman, M. 2004. Measuring reactive species and oxidative damage in vivo and in cell culture: how should you do it and what do the results mean? Br. J. Pharmacol., 142: 231-255.

Hati, S., Sreeja, V., Solanki, J. and Prajapati, J.B. 2015. Significance of proteolytic microorganisms on ACE-inhibitory activity and release of bioactive peptides 
during fermentation of milk. Indian $J$. Dairy Sci., 68(6).

Jocelyn, P.C. 1972. Biochemistry of the SH group.Academic Press, London, UK.

Kapila, S., Jabadolia, L.N., Dang, A.K., Kapila, R. and Arora, S. 2009. Augmentation of biofunctional properties of whey protein on fermentation with $L b$. helveticus.Milchwissenschaft, 64(3).

Khedkar, C.D., Dave, J.M. and Sannabhadti, S.S. 1991. Incidence of Lactobacillus acidophilus in human vaginal and gastrointestinal tracts. Indian J. Comp. Microbiol. Immunol. Infect. Dis., 12:107108.

Korhonen, H. and Pihlanto, A. 2009. Milkderived bioactive peptides: formation and prospects for health promotion in Handbook of functional dairy products. CRC Press, USA, 15:109-124.

Marshall, K. 2004. Therapeutic applications of whey protein. Alternative Med. Review., 9: 136-156.

Mohanty, D.P., Mohapatra, S., Misra, S. and Salu, P.S. 2015. Milk derived bioactive peptides and their impact on human health- A review. Saudi J. Biolog. Sci., 17.

Mohanty, D.P., Tripathy, P., Mohapatra, S., Samantaray, D.P. 2014. Bioactive potential assessment of antibacterial peptide produced by Lactobacillus isolated from milk and milk products. Int. J. Curr. Microbiol. Appl. Sci., 3: 72-80.

Mulder, H., and P. Walstra. 1974. The milk fat globule. Centre for Agricultural Publishing and Documentation, Wageningen, The Netherlands.

Nielsen,C. B. 2009. ABySS-Explorer: visualizing genome sequence assemblies. IEEE Trans. Vis. Comp. Graphics (in revision).

Pan, Y., Rowney, M., Guo, P., Hobman, P. 2007. Biological properties of lactoferrin: an overview. Aust. J. Dairy Technol., 62:31-42.

Parekh, S.L., Balakrishnan, S. and Aparnathi, K.D. 2016. Sensory attributes and physicochemical characteristics of cultured buttermilk prepared by partial substitution of milk with paneer whey. Int. J. Curr. Microbiol. App. Sci. 5(12): 333-348.

doi: http://dx.doi.org/10.20546/ijcmas.2016.51 2.036

Re, R., Pellegrini, N., Proteggente, A., Pannala, A., Yang, M. and Rice-Evans, C. 1999. Antioxidant activity applying an improved ABTS radical cationdecolorization assay. Free Radical Biol. Med., 26:1231-1237.

Rueda, R., J.L. Sabatel, J. Maldonado, J.S. Molina-Font, and A. Gil. 1998. Addition of gangliosides to an adapted milk formula modifies levels of fecalEscherichia coli in preterm newborn infants. J. Pediatr., 133:90-94.

Schmelz, E.M., D.L. Dillehay, S.K. Webb, A. Reiter, J. Adams, and A.H. Merill. 1996. Sphingomyelin consumption suppresses aberrant colonic crypt foci and increases the proportion of adenomas versus adenocarcinomas in $\mathrm{CF} 1$ mice treated with 1,2-dimethylhydrazine: Implications for dietary sphingolipids and colon carcinogenis. Cancer Res., 56:4936-4941.

Schmelz, E.M., M.A. Dombrink-Kurtzman, P.C. Roberts, Y. Kozutsumi, T. Kawasaki, and A.H. Merill. 1998. Induction of apoptosis by fumosinin B1 in HT-29 cells is mediated by the accumulation of endogenous free sphingoid bases. Toxicol. Appl. Pharmacol., 148:252-260.

Shah, C.H. 2011. Antioxidative activity of selected synbiotic fermented dairy products. Master's thesis submitted to Anand Agriculture University, Anand, Gujarat.

Sprong, R.C., M.F.E. Hulstein, and R. van der Meer. 2002. Bovine milk fat components inhibit food-borne pathogens. Int. Dairy J., 12: 209-215.

Steel, R.G.D. and Torrie, J.H. 1980. Principles and Procedures of Statistics-a Biometrical Approach, 2nd edn, New York: McGrawHill., 137-167.

Sun, T., Zhao, S.P. and Wang, H. 2009. ACE- 
inhibitory activity and gammaaminobutyric acid content of fermented skim milk by Lb. helveticus isolated from Xinjiang koumiss in Chaina. Eur. Food Res. Technol., 228:607-612.

Taylor, M.J., and T. Richardson. 1980. Antioxidant activity of skin milk: Effect of heat and resultant sulfhydryl groups. $J$. Dairy Res., 63:1783-1795.

Thompkinson, D.K., and B.N. Mathur. 1989. Effect of buttermilk solids and methyl siloxane on the oxidative stability of lipids in a PUFA-rich infant formula. Ind. J. Dairy Sci., 42:391-393.

Walzem, R.L. 2001. Health enhancing properties of whey proteins and whey fractions. In: Applications MonographNutritional and Beverages, 1-8. Arlington, VA: US Dairy Export Council. Wong, P.Y.Y. and Kitts, D.D. 2003. Chemistry of buttermilk solid antioxidant activity. $J$. Dairy Sci., 86(5): 1541-1547.

\section{How to cite this article:}

Sonali L. Parekh, Smitha Balakrishnan, Subrota Hati and Aparnathi, K.D. 2017. Biofunctional Properties of Cultured Buttermilk Prepared by Incorporation of Fermented Paneer Whey. Int.J.Curr.Microbiol.App.Sci. 6(2): 933-945. doi: http://dx.doi.org/10.20546/ijcmas.2017.602.104 